\title{
STUDI POTENSI HIDROGEN AIR LAUT MELALUI PROSES ELEKTROLISIS SEBAGAI ENERGI TERBARUKAN
}

\author{
Ihza Nursina Salam Aklan ${ }^{\mathrm{a}}$, Cecep E Rustana ${ }^{\mathrm{b}}$ \\ Program Studi Fisika, FMIPA Universitas Negeri Jakarta, Jl. Rawamangun Muka No. 01, Rawamangun \\ 13220, Indonesia

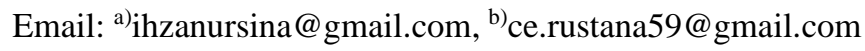

\begin{abstract}
Abstrak
Melimpahnya ketersediaan air laut di dunia mendorong para peneliti untuk terus mengembangkannya menjadi energi yang bisa digunakan oleh umat manusia. Salah satu dari pemanfaatan air laut adalah dengan mengubah nya menjadi hidrogen. Hidrogen dengan mudah dapat diproduksi dan tahan lama dari air laut. Hal ini menunjukan air laut memiliki potensi besar sebagai pengganti bahan bakar fosil yang sampai saat ini masih digunakan. Pada penelitian ini, peneliti melakukkan studi untuk menganalisis hasil-hasil penelitian yang sudah dilakukan untuk memaparkan potensi air laut sebagai sumber energi terbarukan.
\end{abstract}

Kata Kunci: Air laut,Hidrogen,Elektrolisis,Energi

\begin{abstract}
The abundant availability of sea water in the world encourages researchers to continue to develop it into energy that can be used by humanity. One of the uses of sea water is to convert it into hydrogen. Hydrogen can easily be produced and is durable from seawater. This shows that seawater has great potential as a substitute for fossil fuels which are still used today. In this study, researchers conducted a study to analyze the results of research that has been done to explain the potential of sea water as a renewable energy source.
\end{abstract}

Keywords: Sea water, Hydrogen, Electrolysis, Energy

\section{PENDAHULUAN}

Penggunaan energi bagi umat manusia masih terfokus pada energi fosil yang jumlahnya terbatas dimana penggunaannya pun mengakibatkan pemanasan global. Ini mendorong kepada upaya untuk mencari energi yang memiliki keberlanjutan yang baik (sustainable). Air laut adalah sumber daya paling melimpah di planet kita dimana jumlah air laut adalah 97\% dari total seluruh air di planet kita[1]. Maka dari itu air laut sangat cocok sebagai pengganti dari energi fosil yang digunakan pada saat ini.

Air laut bisa dimanfaatkan untuk berbagai hal di kehidupan manusia, salah satu energi yang bersumber dari air laut ialah hidrogen yang dapat digunakan tidak hanya secara langsung sebagai bahan bakar bersih tetapi juga energi yang bisa disimpan karena dapat diangkut dalam jarak yang jauh. Hidrogen ini juga tidak menyebabkan polusi, ringan, dan sustainable karena dapat diproduksi dari air dengan mudah. Selain itu energi matahari dapat dimanfaatkan secara efisien untuk produksi hidrogen. Beberapa cara yang bisa dilakukan untuk mengekstraksi energi dari air laut ialah gradien 
termal, generator angin dan gelombang, elektrolisis, dan fotolisis. Namun, elektrolisis air laut untuk produksi hidrogen adalah teknologi yang menjanjikan paling sederhana [2].

Elektrolisis adalah perubahan kimia, atau reaksi dekomposisi dalam suatu elektrolit oleh arus listrik. Elektrolit larut dalam pelarut polar (misalnya air) dengan terdisosiasi menjadi ion-ion positif (kation-kation) dan ion-ion negatif (anion-anion). Ion negatif disebut anion karena pada saat elektrolisis larutan tertarik ke muatan positif pada anoda, sedangkan ion positif disebut katoda karena melalui larutan akan bergerak menuju muatan negatif (katoda)[3].Melalui proses elektrolisis, air laut dapat diubah menjadi hidrogen yang dapat menggantikan dan setidaknya mengurangi penggunaan energi fosil yang terbatas dan menimbulkan permasalahan pemanasan global. Energi hidrogen yang bersumber dari air laut ini dapat menjadi solusi bagi energi bersih dan salah satu solusi terhadap pengurangan pemanasan global di bumi.

\section{METODE PENELITIAN}

Proses pemanfaatan air laut menggunakan elektrolisis sudah berhasil dilakukan pada beberapa penelitian dan akan direview serta akan dibandingkan semua hasilnya

. Penelitian ini akan menggunakan kajian literatur terhadap hasil-hasil penelitian sebelumnya yang terkait dengan produksi hidrogen dari air laut sebagai energi alternatif melalui proses elektrolisis. Hasil penelitian ini akan dimanfaatkan oleh peneliti untuk pengembangan metode dan pelaksanaan penelitian lebih lanjut yang lebih efektif dan efisien untuk mengembangkan potensi air laut sebagai sumber energi alternatif untuk memproduksi hidrogen.HASIL DAN PEMBAHASAN

Pada bagian ini kami menuliskan beberapa format dasar untuk menuliskan persamaan matematika. Persamaan matematika yang dituliskan harus menggunakan simbol yang sudah baku.

\section{HASIL DAN PEMBAHASAN}

Dalam jurnal ini akan memaparkan beberapa gabungan hasil penelitian dan berupa review hasil atau data untuk menyimpulkan dari hasil-hasil penelitian yang sudah ada yaitu pemanfaatan air laut sebagai energy khususnya dengan proses elektrolisis untuk menghasilkan hidrogen. Sesuai dengan judul bahwa akan membandingkan hasil dari penelitian penelitian sebelumnya untuk melihat potensi dari air laut sebagai energy terbarukan.

Menurut (Kuang,2019) elektrolisis air laut untuk menghasilkan bahan bakar hydrogen sangat bermanfaat bagi energi terbarukan dimana dalam penelitiannya dia menemukan bahwa dalam elektrolit $1 \mathrm{M} \mathrm{KOH}$ dengan konsentrasi tinggi dari $2 \mathrm{M} \mathrm{NaCl}$, Anoda $\mathrm{Ni}^{3}$ yang dipasangkan dengan katoda Ni-NiO- $\mathrm{Cr}_{2} \mathrm{O}_{3}$ bertahan selama 600 jam. Maka dari itu ia berkata bahwa elektroda yang bisa menahan korosi dapat dimanfaatkan sebagai kesempatan untuk menggunakan air laut yang luas di bumi sebagai pembawa energi[4].

Selanjutnya pada penelitian (Rahmi,2019) ditemukan bahwa waktu elektrolisis mempengaruhi 99,9\% dari produksi hydrogen dalam proses elektrolis selain itu produksi hydrogen sudah bisa dilakukan denga tegangan sebesar 0,096 Volt dan penggunaan katalis $\mathrm{CO} 2$ dapat mempercepat produksi hydrogen ,dimana keuntungan yang diperoleh pada elektrolisis menggunakan katalis $\mathrm{CO} 2$ adalah prinsip yang dilakukan sederhana seperti pada elektrolisis konvensional pada umumnya, namun dapat memperoleh gas hidrogen dengan energi yang lebih rendah sehingga memiliki biaya produksi yang lebih rendah[5].

Lalu pada penelitian (Fukuzumi,2017) ditemukan bahwa total potensial energy $\mathrm{H}_{2}$ di laut hitam diperkirakan berjumlah 270 juta ton, jumlah tersebut dapat memproduksi energy thermal sebesar 38,3 juta TJ atau energy listrik sebesar 8,97 juta Gwh, Elektrolisis langsung air laut untuk mengembangkan $\mathrm{H}_{2}$ dan $\mathrm{O}_{2}$ secara selektif tanpa pembentukan klorin atau hipoklorit telah di mungkinkan dengan kriteria desain umum pada $\mathrm{pH}>7,5$ dalam air laut dengan overpotential $(\mathrm{h})$ $<0,48 \mathrm{~V}$. Klorida anion yang terkandung dalam air laut bertindak sebagai katalis untuk mempercepat oksidasi air laut. $\mathrm{H}_{2} \mathrm{O}_{2}$ diproduksi dari air laut dan udara oleh energi matahari telah digunakan secara langsung sebagai bahan bakar dalam sel bahan bakar $\mathrm{H}_{2} \mathrm{O}_{2}$. Dengan demikian, $\mathrm{H}_{2} \mathrm{O}_{2 \text { dapat menjadi }}$ 
alternatif yang berkelanjutan dan bahan bakar hijau untuk barang-barang listrik portabel, karena oksigen, air laut, dan sinar matahari adalah sumber daya yang melimpah, dan pembangkit listrik dimungkinkan dengan sel bahan bakar dengan struktur satu kompartemen sederhana [1]. Berdasarkan kajian ini peneliti akaan mengembangkan penelitian untuk memproduksi hidrogen dari air laut yang diharapkan lebih efektif dan efisien dengan melihat pengaruh waktu dan jenis elektroda terhadap hidrogen yang dihasilkan menggunakan potensi alam Indonesia.

\section{PENUTUP}

Proses elektrolisis adalah salah satu proses yang paling sederhana dan menjanjikan untuk mengubah air laut menjadi hidrogen. Dimana energi hidrogen dari air laut yang diproduksi melalui proses elektrolisis bisa menjadi salah satu dari pilihan energi baru bagi manusia dikarenakan hidrogen dari air laut bisa diproduksi dengan biaya yang cukup ringan karena oksigen, air laut, dan sinar matahari adalah sumber daya yang melimpah serta ramah lingkungan yang memungkinkan hidrogen bisa menjadi pengganti energy fosil dibumi.

\section{REFERENSI}

[1] S. Fukuzumi, Y. M. Lee \& W. Nam, "Fuel Production from Seawater and Fuel Cells Using," Chemsuschem, pp. 4264-4276, 2017.

[2] I. S. Al-Mutaz, T. F. Al-Fariss \& F. A. Abd El-Aleem, "Hydrogen Production From Sea Water," The First Saudi Symposium on Energy, Utilization Conservation, Jeddah, Saudi Arabia, 1990.

[3] S. Y. L. Isana, "Perilaku Sel Elektrolisis Air Dengan Elektroda Stainless Steel," Prosiding seminar nasional Kimia dan Pendidikan Kimia, Yogyakarta, 2010.

[4] K. Yun et al., "Solar-driven, highly sustained splitting of seawater," PNAS, pp. 6624-6629, 2019.

[5] H. I. Rahmi, "Desain Sistem Reaktor dan Pengukuran H2 Berbasis Elektrolisis dengan Katalis CO2,” Universitas Negeri Jakarta, Jakarta, 2019. 
